\title{
ANALYSIS OF CODE MIXING IN A1 CLASS OF ENGLISH EDUCATION STUDY PROGRAM 2016
}

\author{
Lina Nurhasanah ${ }^{1}$ \\ ${ }^{1}$ IKIP Siliwangi \\ ${ }^{1}$ linanurhasanah09@student.ikipsiliwangi.ac.id
}

\begin{abstract}
Code mixing has become a bilingual communication trend that is widely applied by the community in social interactions, especially Indonesian society and students. The method that used in this research is descriptive qualitative. The subjects of this study were English education students who had different ethnic backgrounds and areas of origin. The researcher focused on student utterances that contained by code mixing in the communication. This research was found three types of code mixing used by students namely insertion, alternation, and congruent lexicalization from the English into Indonesia by the students utterances in communication.
\end{abstract}

Keywords: Analysis, Code Mixing

\section{INTRODUCTION}

In the millennial era, many people typically experienced social developments in language use of two or more specific languages. There are many phenomenon in social life, especially in language (Fadillah \& Parmawati, 2020). People typically mixed language at one proper time, with code as a medium of communication in interacting in several circumstances(Hanafiah, Mono, \& Yusuf, 2019). Knowledge of language is crucial to know. Language was utilized to communicating, interacted or expressed feeling and thought as a process that used by every human being (Apridhayati, 2019).In this case, language could be functional and had a purpose for everyone who used it.

The Students adopted many languages in ordinary conversation have became familiar thing even required to be applied in the campus environment as a support for language variations, this raises variations in standard language (Indonesian), dialect, crolect and even English mixed with other languages.In Indonesia there were various kinds of regional languages, the Ministry of Education and Culture (Kemendikbud) said that there are 652 regional languages in Indonesian. Used Indonesian as the national language has enhanced the identity of the people in Indonesia. That why it was not surprisingly for public, traders, or students to mix or switch two languages in a community. The ability to adopt two languages is called bilingualism (Syafaat \& Setiawan, 2019).

Bilingual mixed elements from other languages with the initial language which can be code switching and code mixing (Abduolaye \& Minkailou, 2019). According to Adrean, Daud, \& Kismullah (2019), argued that bilingualism is the skill of a speaker to understand two languages equally well regardless of someone's mastery level. This means that bilingualism is the used of two languages by the speaker in interacting with speakers in various languages. Same with the students who learn English had a reason why they speak in two or more languages, could be 
due to several factors like ethnic background, religion, culture, habits or in the academic environment.

Nowdays, using code mixing in communication is becoming popular among Indonesian students. Mixing languages based on the needs and desires of people to communicate in any situation. Naturally this is not a mistake, because according to Musyken (2000) cited in Ding \& Zhang (2020), mentioned that code mixing is two language used in one sentence where grammatical and lexical is not in the topic. Code mixing is an example of linguistic phenomena (Obrocka, Copley, Gqaza, \& Grant, 2019). Code mixing is synonymous with youth people because it is recognized to increase user confidence as a modern style in the social world (Syafaat \& Setiawan, 2019). In code mixing, when the speaker used one language, she or he included several items such as noun, verb, adjective, phrase and clause from a single lexical item linguistic (Sayuthi, 2020).

Based on contextual factors where the relationship between the speaker, place and topic being discussed. Code mixing can occur in distinct circumstance. When the speaker chooses code mixing in a conversation it does not mean the user conveys an unclear communication but that is one way to make the message clearer (Fahruddiningrum, 2019).

There were several reasons for used code mixing according to Hoffman (1991) cited in Fahruddiningrum (2019), The following is: (1) a term sound is more suitable; (2) to quote some famous expressions or some well-known figure; (3) they want to emphatic about something; (4) interjections to convey the feelings or gain attention; (5) repetition for clarification; (6) intention of clarrifying the speech content for the interlocutor; and (7) expressing group identity.

There were many reasons underlying code mixing users for reasons why they mixed languages. This refers to their ability to used many languages. That's why it's significant to know code mixing theory because someone will constantly be dealing with the phenomenon of code mixing in communication. The writer focused on sociolinguistics in this study. What type of code mixing is used in the utterances that students use? The significant of this study is to provide information to readers and increase knowledge about code mixing that can be found in a community. The theory in this research is code mixing theory from Muysken (2000).

\section{METHOD}

This research used adescriptive qualitative. Subjects involved were some of 2016 English language education students in a small discussion group in class, female (7) and male (3) considering the same background, namely classmates, with an age range of 20-23 years. The researcher focused on the utterances of students who communicate used code mixing (Indonesian-English). In collecting data this research used an observation instrument with listening technique and then wrote it on a small note. Notes and pen as tools to support data collection instruments. The used of this method was intended because the data in the form of student utterences spontaneously directly captured by the writer to note. This study was implemented three steps in analyzing data according to Miles \& Huberman (Rijali, 2018) namely data reduction, data display, conclusion, and verification. 


\section{RESULTS AND DISCUSSION}

\section{Results}

This study was aimed to find out what code mixing is used by students in their conversation in the class. This study found that there are three types of code mixing, namely insertion, alternation and congruent lexicalization. The following is the detailed:

Table1.

\section{Example of Insertion}

\begin{tabular}{|c|c|c|}
\hline No. & Conversation Code Mixing & Meaning \\
\hline 1. & Hari ini pada hadir gak guys? & Are you present today, guys? \\
\hline 2. & $\begin{array}{l}\text { Gak bisa kalau weekend, aku } \\
\text { punya banyak pekerjaan rumah. }\end{array}$ & $\begin{array}{l}\text { I can't go in this weekend, I have a } \\
\text { lot of homework. }\end{array}$ \\
\hline 3. & $\begin{array}{l}\text { Yang background merah putih } \\
\text { ada benderanya, soalnya } \\
\text { sertifikat yang aku gak ada. }\end{array}$ & $\begin{array}{l}\text { which the background is red and } \\
\text { white and a picture of the flag, } \\
\text { because my certificate does not exist. }\end{array}$ \\
\hline 4. & Aku check tapi tidak ada. & I check it but nothing \\
\hline & $\begin{array}{l}\text { Mau tapi sayangnya } \mathrm{Hp} \text { aku } \\
\text { tidak support }\end{array}$ & $\begin{array}{l}\text { I want but my handphone is not } \\
\text { support it. }\end{array}$ \\
\hline
\end{tabular}

\section{Insertion}

The first type is insertion. Insertion in code mixing could be a single word or group of words, but they are not a sentence they are called a phrase (Muysken, 2000; cited in Rohmah, 2019). The Data (1) - (7) above is word type insertion. According to Fahruddiningrum (2019), The word is the smallest part of the language unit. The writer found that the speaker included word from one language into another language. It meant the speaker used Indonesian sentences inserts English word in his utterance. In data (1) there is the word "guys" obtain a single word, which means people, the form of this word is an noun. When the speaker asked to the friends who wouldbe present at an event referred to the interlocutors. In the data (2) - (3) "weekend" refers to the statement of time expressed by the speaker, she rejected invitation because she had homework. The word "background" is intended to provide a specific description of the certificate that the speaker said does not exist. Both of these data did not have a subject and a predicate, but the word represented an expression that is explained by the speaker regarding what is meant in the following sentence. The form of the word as predicate in the data (4) "check" which means to ensured a truth, it was because previously there was the word "I" in the Indonesian language (Aku) identified as the subject who performed an action. The word "support" in data (5) means that it is unfortunate because it cannot help at all. Nothing violate the Indonesian grammatical system at all.

Table 2.

Example of Alternation

\begin{tabular}{cll}
\hline No. & Conversation Code Mixing & \multicolumn{1}{c}{ Meaninng } \\
\hline 6. & $\begin{array}{l}\text { He will do the best, soalnya dia } \\
\text { pekerja keras. }\end{array}$ & $\begin{array}{l}\text { He will do the best, because he is a } \\
\text { hard worker. }\end{array}$ \\
\hline
\end{tabular}


7. You lie to me! Katanya belum tapi You lie to me! He said not yet but udah dikumpulin aja. already collected.

8. Hmm.. gimana ya $\boldsymbol{i}^{\prime} \boldsymbol{m}$ really $\mathrm{Hmm}$... what should I do? I'm really bussy nih, bukannya gak mau ya. bussy, doesn't mean i don't want.

\begin{abstract}
Alternation
The second type of code mixing, alternation is forcing the mixing of forms of language that have compatibility point mixed from a clause (Musyken, 2000; cited in Verschik \& Kask, 2019). Clause is a grammatical and smaller unit than a sentence and larger than a word or phrase and morpheme, there are two types of clauses namely idenpendent (can stand alone) and dependent (can't stand alone) (Fahruddiningrum, 2019). Characteristics of a clause in code mixing were ordinarily from Indonesian into English sentences or vice versa. In the data above, data number (6) is a clause in English and Indonesian. Additionally, data (7) is a idenpendent clause for "You lie to me!" in English followed by Indonesian dependent clause. Whereas in data (8) there is a phrase before the English idenpendent clause "I'm really bussy" followed by an Indonesian clause afterwards.
\end{abstract}

Table 3.

Example of Congruent Lexicalization

\begin{tabular}{|c|c|c|}
\hline No. & Conversation Code Mixing & Meaninng \\
\hline 9. & $\begin{array}{l}\text { Diluar dugaan kita, itu bikin down } \\
\text { banget especially aku. }\end{array}$ & $\begin{array}{l}\text { Outside our unexpected, it really } \\
\text { made us down, especially for me. }\end{array}$ \\
\hline 10. & $\begin{array}{l}\text { Yang aku gak paham tuh yah kok } \\
\text { mau yah dia digituin? kalau aku } \\
\text { really big no! Soalnya bukan apa- } \\
\text { apa ya aku sendiri males banget } \\
\text { kalau mesti berurusan sama tuh } \\
\text { human }\end{array}$ & $\begin{array}{l}\text { What I don't understand is why he } \\
\text { wants to be treated like that? if it } \\
\text { were me, really big no! because it's } \\
\text { not about anything but I'm lazy if I } \\
\text { have to deal with human like that. }\end{array}$ \\
\hline 11. & $\begin{array}{l}\text { Aku bener-bener sorry banget but } \\
\text { aku gak ada pulsa. }\end{array}$ & $\begin{array}{l}\text { I'm really sorry, but I have no credit } \\
\text { balance left }\end{array}$ \\
\hline
\end{tabular}

\title{
Congruent Lexicalization
}

The latter type of code mixing theory is congruent lexicalization. Congruent lexicalization is the placement of words or phrases in more or less numbers that are inserted in two languages randomly, it divided grammatical structures and can be filled lexically with element from other languages (Aini, 2019). In data (90) - (11) was found by the writer is congruent lexicalization. There were words "down" and "especially" in the data (9). The data (10) there were "really big no!" is English phrases and "human" is the word of English in Indonesian sentences. Furthermore, "sorry" and "but" in the data (11) were English words inserted in Indonesian sentences.

\section{Discussion}

Based on the data findings and analysis of code mixing that used in students conversation. It was found there were 27 data from Indonesian-English code mixing which contained the first type, namely insertion of $13(48.15 \%)$ data, the most widely used words were English and Indonesian sentences. The second type is alternation was found $8(29.62 \%)$ data. Indicated as the last type is congruent lexicalization of $6(22.22 \%)$ data. 


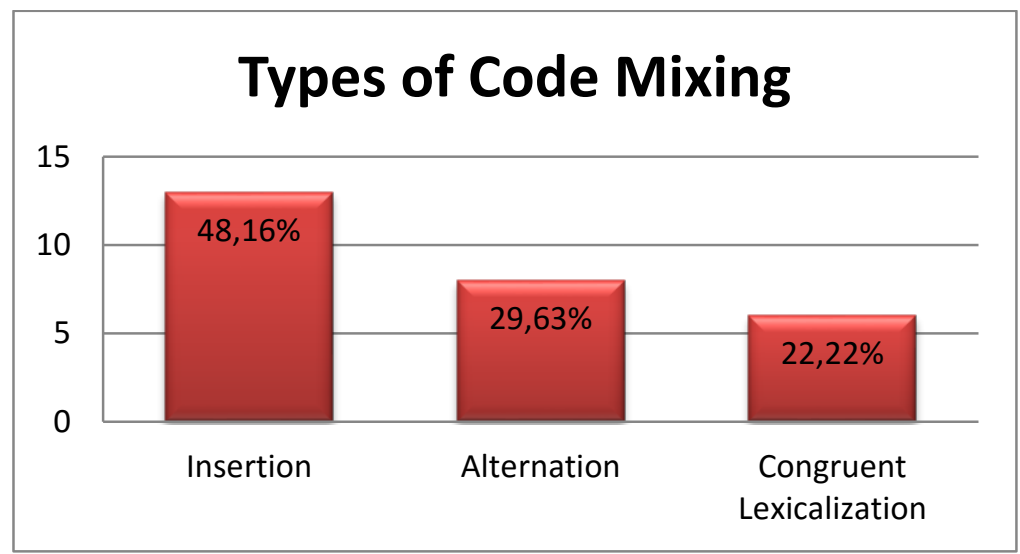

Fig. 1. The Percentage of Code-Mixing data in each type

The most substantial reason why students used code mixing, it because they were used to mixing their own local language with the Indonesian national language. Mixed Indonesian and English was useful for students to increase their knowledge of the language they were learn and implemented it in daily conversation. so that it can improve students' abilities in socializing or interacting in their environment and community.

\section{CONCLUSION}

The conclusions from the results and discussion of this study. Based on the code mixing used by students. There are three types of code mixing were found: Insertion, many of the students used this type such as inserted an English word into Indonesian sentences but did not change the Indonesian structure. The second type is Alternation, the writer found that students mixed two different languages and both have grammatical and lexical level. The third type is congruent lexicalization, students slip random English word or phrase into the structure of the Indonesian language.

\section{ACKNOWLEDGMENTS}

The thankfulness is addressed to IKIP SILIWANGI. Then, the writers express their gratitude to the lecturers and friends who have participated in this research.

\section{REFERENCES}

Abduolaye, I., \& Minkailou, M. (2019). Understanding the Nature of Code-Switching and Code-Mixing of Songhay Speakers of French. Global Journal of Human-Social Science: G Linguistics \& Education, 19(2), 1-14.

Adrean, M. R., Daud, B., \& Kismullah. (2019). An Analysis of Code Mixing in Indonesian Movie Cek Toko Sebelah. Research in English and Education (READ), 4(4), 147-154.

Aini, I. (2019). Code Mixing In Suhay Salim Beauty Vlogger. Language Horizon, 7(1), 1-7. Apridhayati, R. (2019). The Analysis Of Code Mixing Used By Junior High School Students. ELT (English Language Teaching Prima Journal), 1(1), 1-9.

Ding, J., \& Zhang, J. (2020). College Students' Attitude toward“Chinese + English” Code Mixing. Journal of Contemporary Educational Research, 4(2), 64-67. 
Fadillah, D. N., \& Parmawati, A. (2020). An Analysis Of Code Switching And Factor Motivation In Nessie Judge Vlog. PROJECT (Professional Journal of English Education), 3(4), 459-464.

Fahruddiningrum, F. (2019). Sasak-Taliwang Code Mixing Used Among Inhabitants of Jantuk Village Mantang in Central Lombok. International Journal of Multicultural and $\begin{array}{lll}\text { Multireligious } \quad \text { Understanding, } & \text { 494-503. }\end{array}$ https://doi.org/http://dx.doi.org/10.18415/ijmmu.v6i5.1105

Hanafiah, R., Mono, U., \& Yusuf, M. (2019). Code-Mixing Employed in ExaminerExaminee's Interaction: A Sociolinguistic Study. Advances in Social Science, Education and Humanities Research, 411(Icoelt 2019), 14-17.

Muysken, P. (2000). Bilingual Speech A Typology Of Code-Mixing. Cambridge University Press.

Obrocka, M., Copley, C., Gqaza, T., \& Grant, E. (2019). Prevalence Of Code Mixing In SemiFormal Patient Communication In Low Resource Languages of South Africa. ArXiv, 1911(05636v3), 1-4.

Rijali, A. (2018). Analisis Data Kualitatif. Alhadharah: Jurnal Ilmu Dakwah, 17(33), 81-95.

Rohmah, A. N. (2019). Code-Mixing Used By The Family Of Gen Halilintar's Vlog. Universitas Muhammadiyah Surakarta.

Sayuthi, M. (2020). Code Mixing on SMS : Emerging Allay Language. Journal of Linguistics, English Teaching and Education, 1(1), 5-8.

Syafaat, P. M. F., \& Setiawan, T. (2019). An Analysis of Code Mixing in Twitter. Advances in Social Science, Education and Humanities Research, 297(Icille 2018), 276-281.

Verschik, A., \& Kask, H. (2019). Estonian-English Code Alternation in Fashion Blogs: Structure, Norms and Meaning. Multilingualism in the Baltic States, 307-335. 